\title{
Genetic diversity of the pan-European freshwater mussel Anodonta anatina (Bivalvia: Unionoida) based on CO1: new phylogenetic insights and implications for conservation
}

\author{
ELSA FROUFE ${ }^{\mathrm{a}, *}$, CARINA SOBRAL $^{\mathrm{a}}$, AMÍLCAR TEIXEIRA $^{\mathrm{b}}$, RONALDO SOUSA ${ }^{\mathrm{a}, \mathrm{c}}$, SIMONE VARANDAS $^{\mathrm{d}}$, \\ DAVID C. ALDRIDGE ${ }^{\mathrm{e}}$ and MANUEL LOPES-LIMA ${ }^{\mathrm{a}, \mathrm{f}}$ \\ ${ }^{a}$ Interdisciplinary Centre of Marine and Environmental Research (CIIMAR/CIMAR), University of Porto, Porto, Portugal \\ ${ }^{\mathrm{b}}$ CIMO-ESA-IPB Mountain Research Centre, School of Agriculture, Polytechnic Institute of Bragança, Bragança, Portugal \\ ${ }^{\mathrm{c}}$ CBMA - Centre of Molecular and Environmental Biology, Department of Biology, University of Minho, Braga, Portugal \\ ${ }^{\mathrm{d}}$ CITAB-UTAD - Forestry Department, Centre for Research and Technology of Agro-Environment and Biological Sciences, \\ University of Trás-os-Montes and Alto Douro, Vila Real, Portugal \\ e Aquatic Ecology Group, Department of Zoology, University of Cambridge, Cambridge, UK \\ ${ }_{\mathrm{f}}^{\mathrm{f}}$ ICBAS - Institute of Biomedical Sciences Abel Salazar, University of Porto, Porto, Portugal
}

\begin{abstract}
1. The duck mussel, Anodonta anatina, has been described as abundant and widespread in Europe. However, it is listed as near threatened or threatened in several countries owing to severe declines in abundance and/or spatial distribution.

2. Despite its potential ecological importance and conservation status almost nothing is known regarding its genetic diversity.

3. As a preliminary analysis, variation within the cytochrome oxidase 1 mitochondrial gene was determined from European specimens from Portugal in the south west, to Ukraine in the east, and Sweden in the north.

4. Three major mtDNA clades were retrieved: clade 1 includes all the individuals from Iberia, except those from the Ebro basin; clade 2 includes all the European non-Iberian and non-Italian samples; and clade 3 includes all the individuals from Italy and from the Ebro basin. AMOVA analysis revealed significant genetic differences among the three clades. Within each of the major clades, several geographically related haplogroups were also retrieved, especially in Iberia, where four genetically distinct groups (North-West, South-Central, South-West and Ebro) were revealed.

5. Given the evidence of regional declines of A. anatina in Europe, the confirmation of geographically distinct genotypes indicates a need for the development of management strategies directed towards the conservation of localized populations.

Copyright (C) 2014 John Wiley \& Sons, Ltd.
\end{abstract}

Received 18 May 2013; Revised 29 January 2014; Accepted 23 February 2014

KEY WORDS: Anodonta anatina; river; genetics; invertebrates; molluscs

*Correspondence to: Elsa Froufe, Aquatic Ecology and Evolution Group, Interdisciplinary Centre of Marine and Environmental Research (CIIMAR/CIMAR), University of Porto, Porto, Portugal. Rua dos Bragas 289, 4050-123 Porto, Portugal. E-mail: elsafroufe@gmail.com 


\section{INTRODUCTION}

Unionoid mussels are among the most critically endangered fauna and are globally in decline (Strayer, 2008). Conserving unionoid populations has wider importance because these animals are responsible for important ecosystem functions and services (e.g. food resource to higher trophic levels, clearing the water, control of the amount and composition of suspended particles, nutrient cycling and provision of habitat for other organisms; Aldridge et al., 2007; Vaughn, 2010; Sousa et al., 2011, 2012). In addition, their unusual life cycle, that requires a host fish species for larval (glochidia) development and dispersal (Barnhart et al., 2008), has the potential to drive genetic isolation between populations (Douda et al., 2013), which may lead to phylogeographic patterns of conservation importance.

While North America is known as a global centre of endemism for freshwater mussels, with over 300 species and subspecies described (Williams et al., 1993; Graf and Cummings, 2007), in Europe the real number of species is still unknown but is considered to be relatively low (about 16). It is interesting to note that the number of phylogeographic and/or genetic diversity studies on European freshwater mussels is surprisingly low (Nagel et al., 1996; Machordom et al., 2003; Araujo et al., 2005, 2009a, b; Geist et al., 2010; Skidmore et al., 2010), especially when compared with those from North America (King et al., 1999; Serb et al., 2003; Chong et al., 2008; Elderkin et al., 2008; Zanatta and Murphy, 2008; Mock et al., 2010, 2013; Zanatta and Harris, 2013; Inoue et al., 2014).Understanding the spatial patterns of unionoid mussel lineages may be especially interesting in southern European peninsulas because these have been shown to have served as refugia during cold periods in the Pleistocene, acting both as centres of origin of endemisms and as sources from which formerly glaciated areas were recolonized during interglacial periods (see Weiss and Ferrand, 2007, for a review). In southern Europe, the main Pleistocene glacial refugia include the Balkans, the Carpathian Mountains, the Italian Peninsula and Iberia (Hewitt, 2000). It is generally accepted that many temperate European species were forced to shift their distributions into the three Mediterranean refugia because of repeated glaciations and climatic fluctuations (Hewitt, 1999). For example, in the Iberian Peninsula, many vertebrate, invertebrate and plant species show strong genetic subdivisions, reflecting at least two refuges for each species that indicate not only the occurrence of different glacial refuges in the Iberian Peninsula, but also different glacial refuges for the same species (see Gómez and Lunt, 2007, for a review). However, several other studies have also revealed northern refugia (i.e. non-Mediterranean) in a number of vertebrate and invertebrate European species (Bilton et al., 1998; Bunje, 2005; Pauls et al., 2006; Benke et al., 2009).

The duck mussel, Anodonta anatina (Linnaeus, 1758), is a convenient model organism for testing biogeographical hypotheses concerning European freshwater ecosystems, especially owing to its occurrence throughout most of the continent. This freshwater mussel occurs in Europe and Asia below $65^{\circ} \mathrm{N}$ latitude down to Portugal, Sicily and Turkey and extending as far east as Siberia (Lake Baikal) (Graf, 2007). Anodonta anatina is a habitat generalist, inhabiting both lentic and lotic waters, ranging from small streams to large rivers, lakes and reservoirs (Hinzmann et al., 2013). While little is known on the global conservation status of $A$. anatina, some regional studies indicate population declines around Europe, resulting in the species being protected in some European countries (e.g. Germany and Luxembourg) and listed as near threatened or threatened in Austria, Germany, Ireland and Romania (Sárkány-Kiss, 2003; Reischütz and Reischütz, 2007; Byrne et al., 2009; Binot-Hafke et al., 2011). Moreover, as with most unionoids, A. anatina presents great phenotypic plasticity having had more than 400 synonyms assigned (Nagel et al., 1996; Graf and Cummings - http:// www.mussel-project.net; March 2013). For example, the major morphological differences observed among $A$. anatina populations from distinct rivers or basins has resulted in more than 20 synonyms being described for Iberia alone (Araujo et al., 2009b). Further complicating this picture, synonyms of this species are generally mixed with 
those of Anodonta cygnea (Linnaeus, 1758) with which it has frequently been misidentified. In fact, the inappropriate use of shell characters such as contour line, thickness, or colouring has been a persistent and contentious problem that allowed taxonomists to exaggerate the extant number of bivalve species. Reliable conchological characters traditionally used to identify taxonomic units are very limited because of the high morphological plasticity of shells, which often reflect different ecophenotypes (Sousa et al., 2007; Zieritz and Aldridge, 2009; Zieritz et al., 2010).

Thus, despite being the most widespread European unionid species, there are few data available on the autecology of $A$. anatina, and no molecular studies have encompassed the species' supposed entire range.

In the present study, the Iberian Peninsula was chosen for several reasons as a detailed study area to investigate the genetic variation of A. anatina. First, it has a low number of artificial connections between river systems compared with central Europe. Second, despite the fact that $A$. anatina has been generally considered to have a wide host fish spectrum (Bauer, 2001), recent studies conducted in Iberia and central Europe suggest a narrow host range that is restricted to native fishes, mainly cyprinids (Douda et al., 2013). Third, fish faunas in Iberia are quite distinct from those in Central Europe $(73 \%$ of species are endemic to Iberia) and even inside the Iberian Peninsula major river basins have different fish assemblages (Maceda-Veiga, 2013). Moreover, phylogeographical studies in Iberian freshwater fishes, including cyprinids, have demonstrated the existence of evolutionarily distinct groups within each species, which suggests multiple refugia during glacial periods (Callejas and Ochando, 2000; Carmona et al., 2000; Coelho et al., 2005; Doadrio et al., 2013). Given the potential for the biogeography of host fishes to affect the genetic structure of unionoid populations, $A$. anatina in Iberia would be predicted to display phylogeographical patterns reflective of host fish isolation. Thus, the genetic diversity of this species was investigated using novel and already available cytochrome c oxidase subunit I (CO1) sequence data. In addition, by comparing the Iberian data with other European populations across the species range, the study aimed to investigate how $A$. anatina populations are genetically structured across its range and how this might facilitate future conservation planning.

\section{METHODS}

\section{Specimens examined}

All $A$. anatina CO1 sequences available on GenBank were downloaded, providing 23 sequences from Portugal, Spain, Sweden, Poland and Ukraine (Table 1). In addition, A. anatina individuals (total 61) were sampled from the following 10 major Iberian Peninsula river basins: Minho, Douro, Vouga, Mondego, Tejo, Guadiana, Sado, Guadalquivir, Barbate and Ebro (Table 1). Additional material was provided by collaborators, across the species range, in 29 samples from the following areas: Danube Basin and Lake Balaton (Hungary); Elbe Basin (Czech Republic); Lake Maggiore (Italy); Thames and Bure Basins (UK) and Dniester Basin (Ukraine) (Table 1).

The distribution of $A$. anatina samples previously available on GenBank and those newly sequenced is summarized in Figure 1.

\section{DNA extraction, amplification and sequencing}

Whole genomic DNA was extracted from small tissue pieces preserved in $96 \%$ ethanol, using a standard high-salt protocol (Sambrook et al., 1989). A fragment of $\sim 700 \mathrm{bp}$ of CO1 gene was amplified by PCR using the universal primer HCO2198 (Folmer et al., 1994) paired with UNIOCOII.2 (Walker et al., 2006) and the modified versions, i.e., LCO22me2 and HCO700dy2 (Walker et al., 2006, 2007). The PCR conditions $(25 \mu \mathrm{L}$ reactions) were as follows and identical for both primer pairs: each reaction contained $2.5 \mu \mathrm{L} 10 \times$ Invitrogen PCR Buffer, $0.5 \mu \mathrm{L} 10 \mathrm{mmol} \mathrm{L}^{-1}$ of each primer, $1.5 \mu \mathrm{L}$ $50 \mathrm{mmol} \mathrm{L}^{-1} \mathrm{MgCl}_{2}, 0.5 \mu \mathrm{L} 10 \mathrm{mmol} \mathrm{L}^{-1}$ dNTPs, $0.1 \mu \mathrm{L}$ Invitrogen Taq DNA Polymerase and approximately $2 \mu \mathrm{L}$ DNA template. The cycle parameters were: initial denaturation at $94^{\circ} \mathrm{C}$ for $3 \mathrm{~min}$, denaturation at $94^{\circ} \mathrm{C}(30 \mathrm{~s})$, annealing at $45^{\circ} \mathrm{C}$ (HCO2198 and UNIOCOII.2) or $48^{\circ} \mathrm{C}$ 
Table 1. List of samples examined with respective GenBank accession codes and information about population, river basin, country, haplotype and clades. All samples are from Anodonta anatina except the ones used for outgroups, i.e. Pseudanodonta complanata (JQ253891, JQ253892, DQ060172, DQ060173) and Anodonta cygnea (GU230749, AA388)

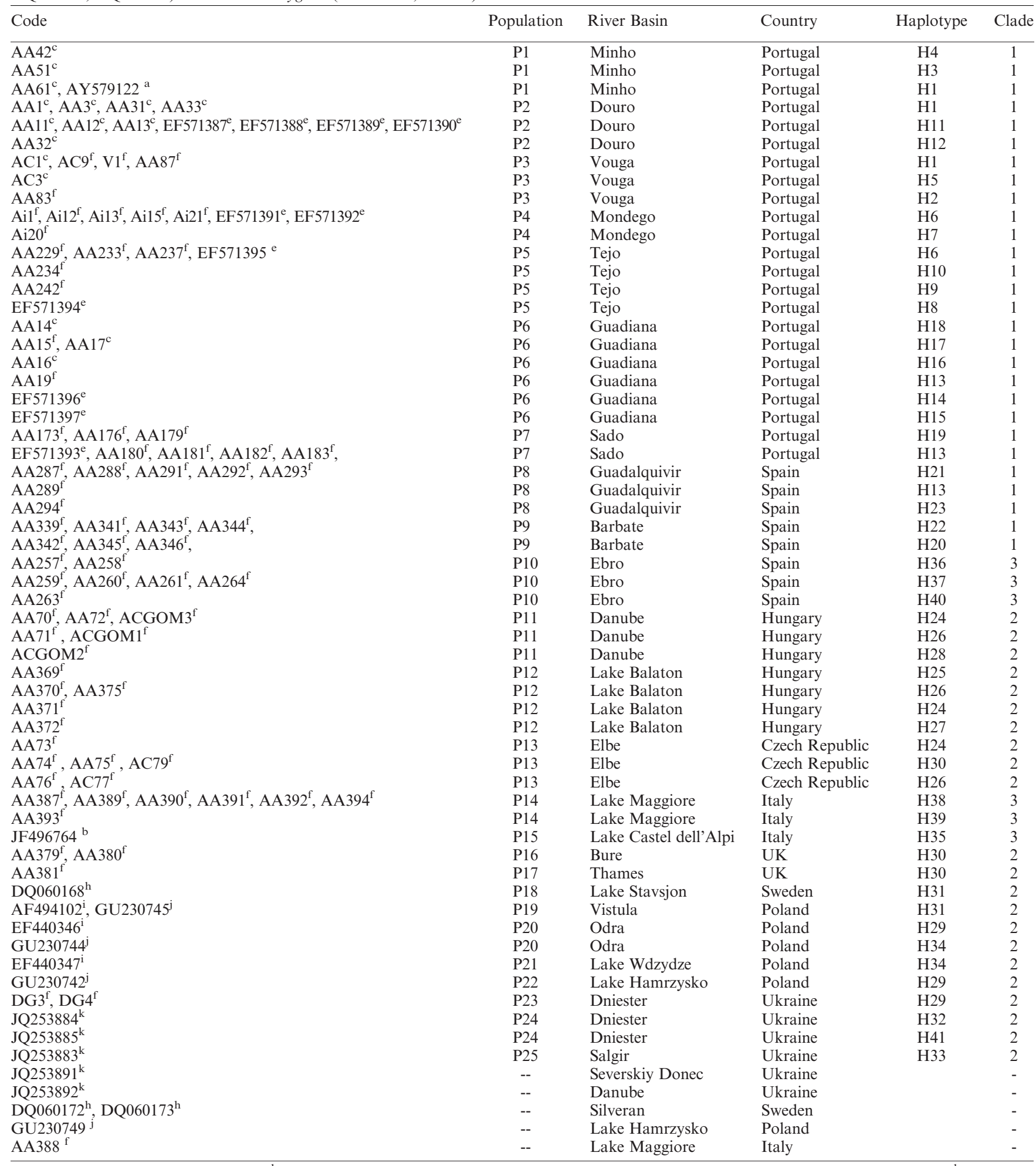

${ }^{\mathrm{a}}$ listed on GenBank as Anodonta sp.; ${ }^{\mathrm{b}}$ listed on GenBank as A. cygnea; ${ }^{\mathrm{C}} \mathrm{Hinzmann}$ et al., 2013 (GenBank n ${ }^{\mathrm{os}}$ : KC583446-KC583463); ${ }^{\mathrm{d}} \mathrm{Huff}$ et al., 2004; ${ }^{\mathrm{e}}$ Reis et al. 2013, (GenBank n ${ }^{\text {os }}$ : EF571397.1-EF571387.1); ${ }^{\mathrm{f}}$ This study (GenBank n ${ }^{\text {os }}$ : KC583464-KC583519); ${ }^{\mathrm{g}}$ Plazzi et al., 2011; ${ }^{\mathrm{h}} \mathrm{Källersjö}$ et al., 2005; ${ }^{\mathrm{i}}$ Soroka, 2008; ${ }^{\mathrm{j}}$ Soroka, 2010; ${ }^{\mathrm{k}}$ Yanovich (unpublished). 


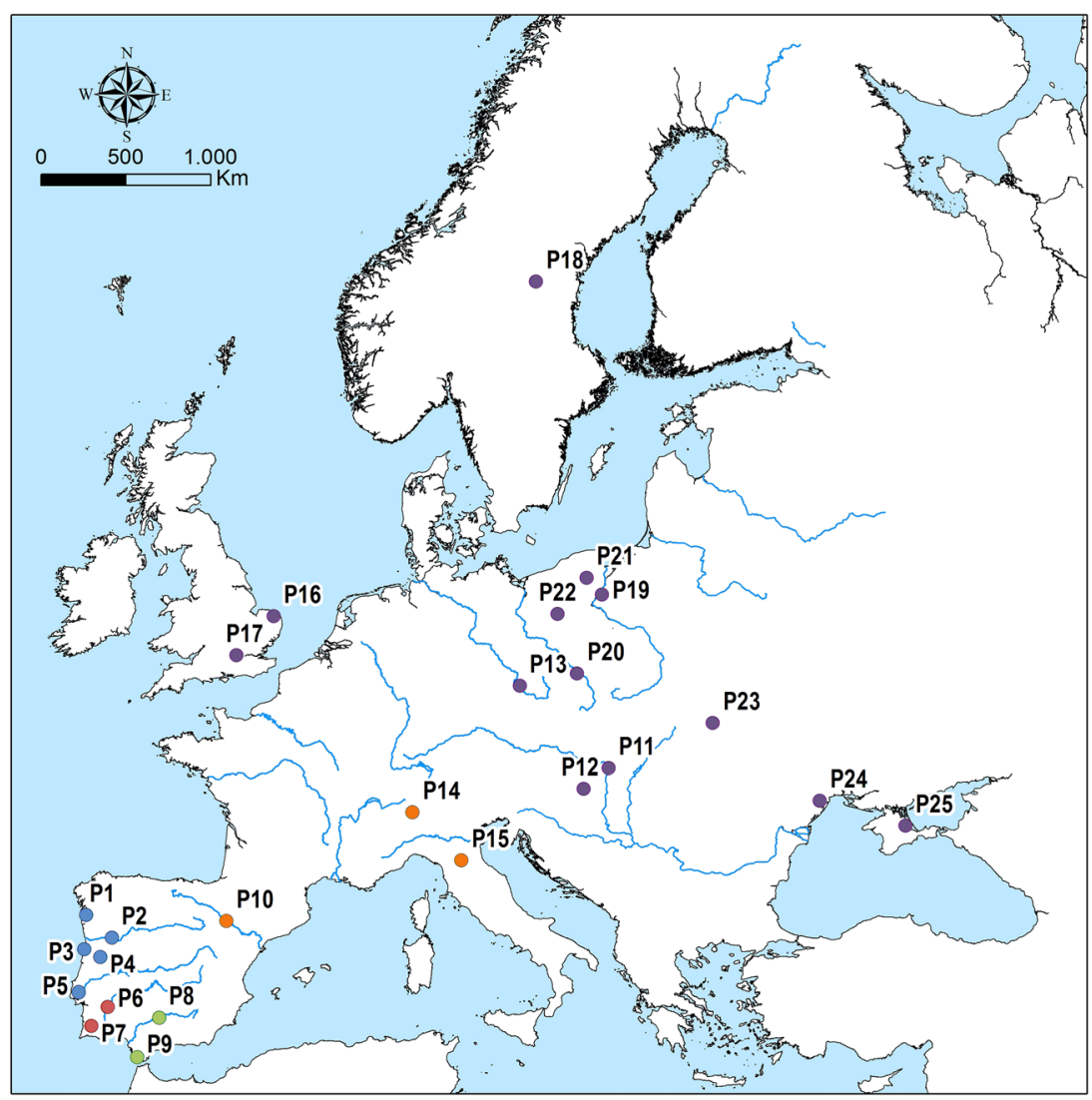

Figure 1. Map showing the location of Anodonta anatina samples from Europe. Population codes (P) follow Table 1. Colours represent the geographic distribution of the major groups as in the phylogeny (Figure 2).

(LCO22me2 and HCO700dy2) (40 s) and extension at $72^{\circ} \mathrm{C}(60 \mathrm{~s})$ repeated for 40 cycles and a final extension at $72^{\circ} \mathrm{C}$ for $10 \mathrm{~min}$. Amplified DNA templates were purified and sequenced by a commercial company, Macrogen, using the same primers.

\section{Phylogenetic analyses and genetic diversity}

Owing to the common misidentification between $A$. cygnea and $A$. anatina, all the A. cygnea $\mathrm{CO} 1$ sequences available were downloaded. A preliminary analysis on these sequences showed conclusively that all but one were $A$. cygnea (see Results). Selected outgroups included one $A$. cygnea individual previously published, one sequenced for this study, and four individuals of Pseudanodonta complanata (Rossmässler, 1835) (Table 1).

Chromatograms were checked by eye using ChromasPro 1.41 (technelysium.com.au) and the alignment was performed using Bioedit v.5.0.9.
(Hall, 1999). This data set was then analysed using maximum likelihood (ML) and Bayesian inference (BI) methods. The best-fit model of nucleotide substitution evolution under the corrected Akaike Information Criterion was estimated using JModelTest 0.1.1 (Posada, 2008). The Tamura and Nei (1993) model of sequence evolution with the proportion of invariable sites estimated from the data $(\operatorname{TrN}+\mathrm{G} ; \mathrm{G}=0.3380)$ was chosen. ML trees were built in PhyML (Guindon and Gascuel, 2003) with 1,000 bootstrap replicates and searching for the best-scoring ML tree. Phylogenetic BI was performed using MrBayes version 3.1.2 (Ronquist and Huelsenbeck, 2003). Two independent runs $10^{7}$ generations long were sampled at intervals of 100 generations producing 100000 trees. Burn-in was determined upon convergence of $\log$ likelihood and parameter estimation values using Tracer 1.4 (Rambaut and Drummond, 2007). For each of the major clades 
obtained in the phylogeny, sequence divergence was assessed using MEGA5 software (Tamura et al., 2011).

\section{Population geographic structure}

To evaluate relationships among closely related haplotypes, sequences were joined in a statistical parsimony network constructed under a 95\% criterion using TCS 2.1 (Clement et al., 2000). This method is intended to detect potential spatial patterns according to the distribution of haplotypes. Moreover, this technique allows a more detailed display of population information than strictly bifurcating trees, being particularly suited to the analysis of single-species gene genealogies (Posada and Crandall, 2001).

ARLEQUIN 3.5 software (Excoffier and Lischer, 2010) was used to run the analysis of molecular variance (AMOVA) to estimate the hierarchical distribution of mtDNA genetic differentiation within and among populations, using $\Phi_{\mathrm{ST}}$ (from the absolute number of nucleotide differences) and with $10 \quad 000$ permutations. AMOVA was used to assess possible differences among populations of $A$. anatina for (i) Iberia alone; and (ii) its entire range. To assess the levels of genetic differentiation among Iberian $A$. anatina populations, pairwise population differentiation values $\left(\Phi_{\mathrm{ST}}\right)$ were calculated using the same software and associated probability values were quantified using uncorrected p-distance and 10000 permutations.

\section{RESULTS}

\section{Phylogenetic analyses and genetic diversity}

The CO1 alignment consisted of 113 DNA sequences of $A$. anatina specimens, four of $P$. complanata and two of $A$. cygnea (Table 1 ). Aligned sequences had a total length of $590 \mathrm{bp}$, with 61 polymorphic and 53 parsimony informative sites. No indels and no unexpected stop codons were observed after translating all sequences to amino acid.

The tree topologies resulting from the single tree recovered from $\mathrm{ML}$ and $\mathrm{BI}$ approaches were congruent, with a sole exception between the two phylogenies (see below). The results of both analyses are shown in Figure 2 and it seems that the phylogeny of the Anodonta genus needs further evaluation, because $A$. cygnea and $P$. complanata form a sister clade to $A$. anatina. Three major mtDNA clades were retrieved with high support: the first includes all the individuals from Iberia, except those from the Ebro basin (clade 1); the second, all the European non-Iberian and nonItalian samples (clade 2); and the third, basally related to all the other $A$. anatina samples, includes all the individuals from Italy and from the Ebro Basin (clade 3). The divergence between them (uncorrected distances) varied from 1.9\% between clade 1 and clade 2 to $3.1 \%$ between clade 1 and clade 3 (Table 2).

A further analysis of each clade showed additional geographic patterns. Clade 1 is divided into three major well-supported groups: one corresponded to all north-west Iberian populations (1-5, Figure 1 and Table 1); another included south-west populations (6 and 7, Figure 1 and Table 1); and the third encompassed all the south-central Iberian populations (8 and 9, Figure 1 and Table 1). As explained above, the Ebro population does not cluster inside clade 1, but inside clade 3 . Thus, within the Iberian Peninsula, these results demonstrate the existence of four geographically related groups, with an average genetic distance (uncorrected distances) between them, ranging from $1.0 \%$ to $3.5 \%$ (Table 2 ).

Non-Iberian populations all cluster inside the geographically diverse clade 2 , with the exception of the Italian samples. This clade includes 32 individuals collected in central and northern Europe (Table 1), without clear geographically related groups (Figure 2).

In clade 3, all the Italian samples from Lake Maggiore (population 14, Figure 1 and Table 1) grouped together inside a well-supported group. It is interesting that its sister taxa were revealed to be the Iberian Ebro Basin samples (population 10, Figure 1 and Table 1). A previously published sequence from Lake Castel dell'Alpi, Italy (population 15, Figure 1 and Table 1) and listed as A. cygnea on GenBank (JF496764) was grouped with the Ebro Basin, Iberia, inside clade 3 in the $\mathrm{BI}$ tree, but not in the ML tree (the sole exception between the two phylogenies), where it was placed 


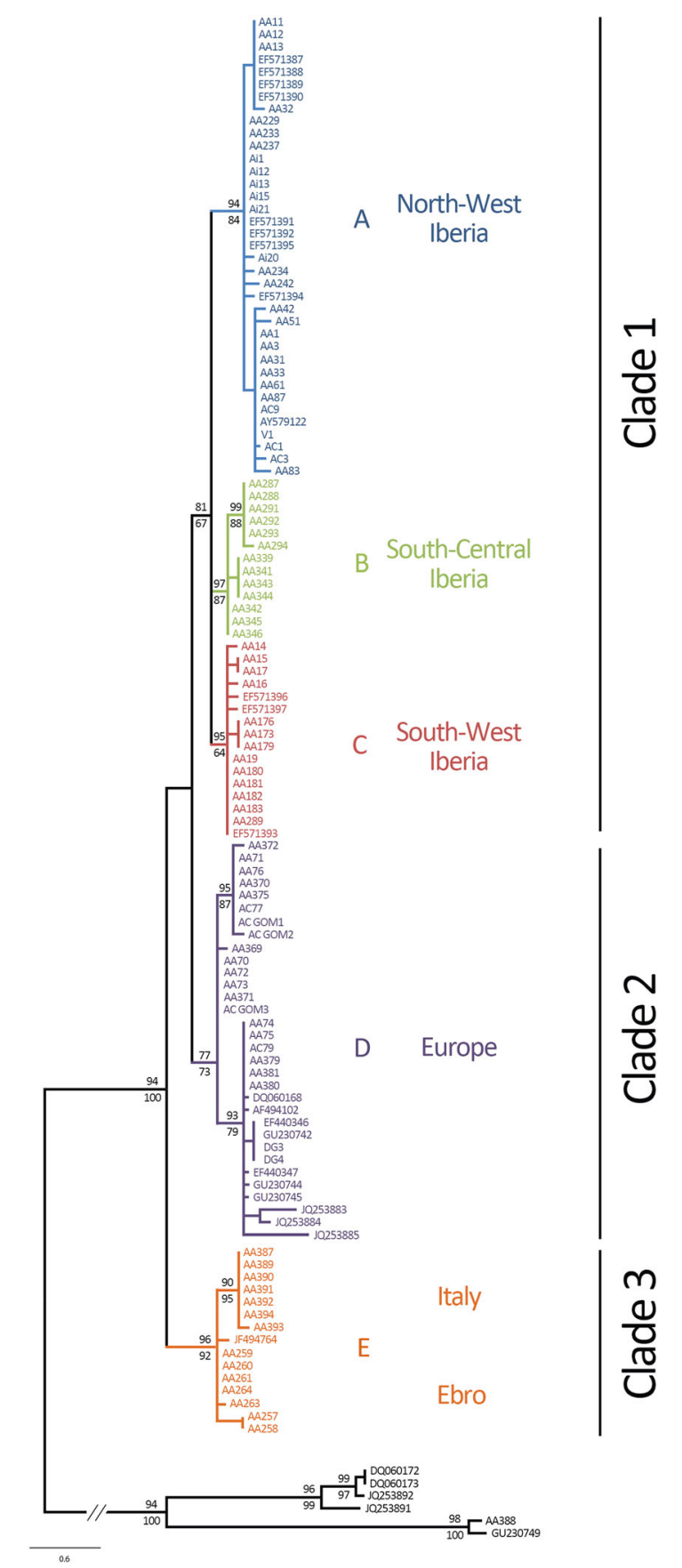

Figure 2. Phylogenetic tree obtained by BI analysis of $113 \mathrm{CO} 1$ sequences (590 bp) of Anodonta anatina specimens with Pseudanodonta complanata and Anodonta cygnea individuals as outgroups. Support values (\%) are given as Bayesian posterior probability (BI) above nodes and bootstrap support (ML) below nodes. Some values were omitted for clarity at short nodes within clades. The tree topologies resulting from ML and BI approaches were congruent, with one sole exception found between BI and ML phylogenies (JF496764), which was the grouping with Ebro Basin (Iberia) inside clade 3 in the BI tree, but not in the ML tree, where it was placed as sister to all the other samples in clade 3. Colours highlight the major mtDNA groups found that correspond to the geographic distribution as seen in Figure 1; and letters A-E relate to the major haplotypes groups as in Figure 3. as sister to all the other samples in clade 3. From all the sequences available on GenBank under study here, this was the only mislabelled specimen detected.

\section{Population geographic structure}

At the $95 \%$ confidence limit, TCS produced a single network shown in Figure 3. From all the A. anatina sequences analysed, 41 distinct haplotypes were resolved, 23 of which occurred only once with the most frequent haplotype (H6) occurring in 11 individuals across the species range (Table 1). The distribution of Iberian haplotypes in the network reveals further interesting spatial patterns: the north-western Iberian populations are at one of the tips of the network, and comprise the two most frequent haplotypes ( $\mathrm{H} 1$ and $\mathrm{H} 6)$ across it. The individuals from south-central Iberia appear between the north-western (seven mutations from it) and the south-western (four mutations from it) populations. This latter group includes one haplotype (H13) that is shared among individuals from three distinct populations $(6,7$, and 8; Table 1 and Figure 1) including the Guadalquivir basin (south-central Iberia). As seen in the phylogeny, the fourth Iberian group (Ebro) is closer to those from Italy (H35, H38 and H39; Figure 3), with its haplotypes (H36-H37-H40) being 27 mutations from the closest Iberian populations (south-west group).

The vast majority of the European non-Iberian and non-Italian haplotypes from the central and north European populations cluster close together in an internal position in the species network. Interestingly, the three supported groups depicted in the phylogeny were not represented in the same way in the network; although all the haplotypes from Hungary (including those from Lake Balaton) and three from the River Elbe in the Czech Republic (H24-28 - Figure 3) were distinct from the individuals from the UK, Sweden, Czech Republic, Poland and Ukraine (H29-H33; Figure 3). In between these European and Italian +Ebro haplotypes (at exactly seven mutations each way) appears H34, a haplotype present in only three individuals from Poland. Another interesting result was the position in the network of one 
Table 2. Left: Mean genetic divergence between the main Anodonta anatina mitochondrial clades (Figure 2). Right: Mean genetic divergence between the Iberian A. anatina mitochondrial groups (Figure 2). The number of base differences per site from averaging over all sequence pairs, individuals (n) and haplotypes (k) are shown; standard error estimate(s) are shown above the diagonal, in bold. The analysis involved 113 CO1 mtDNA sequences

\begin{tabular}{lccccclcrrrrr}
\hline & Clade 1 & Clade 2 & Clade 3 & $\mathrm{n}$ & $\mathrm{K}$ & & North-West & South-Central & South-West & Ebro & $\mathrm{n}$ & $\mathrm{k}$ \\
\hline Clade 1 & & $\mathbf{0 . 0 0 6}$ & $\mathbf{0 . 0 0 9}$ & 66 & 23 & North-West & & $\mathbf{0 . 0 0 4}$ & $\mathbf{0 . 0 0 4}$ & 0.007 & 37 & 12 \\
Clade 2 & 0.019 & & $\mathbf{0 . 0 0 8}$ & 32 & 12 & South-Central & 0.016 & & 0.003 & 0.006 & 13 & 5 \\
Clade 3 & 0.031 & 0.024 & & 15 & 6 & South-West & 0.014 & 0.010 & 0.006 & 16 & 7 \\
\hline
\end{tabular}

unique haplotype from Ukraine (H41), which appears at the other tip of the network and eight mutations away from the Iberian (Ebro Basin) haplotype H35. Moreover, the other five individuals from Ukraine have four distinct haplotypes (Table 1), with H33 (Figure 3) being also several mutations from the closest haplotype in the network.

Although some care must be taken owing to the small sample size, the results from AMOVA showed that $54.25 \%$ of the overall variation in $A$. anatina across its range (major groups corresponding to the three major clades obtained in the phylogeny) was found among regions. In contrast, only $9.93 \%$ of total mitochondrial haplotype variation occurred within populations, with all structured levels presenting highly significant genetic differences (Table 3). When testing for structure inside Iberia alone, $71.92 \%$ of overall variation of the species was found among the four regions tested but $21.37 \%$ occurred within populations. Again, all structured levels presented highly significant genetic differences (Table 3 ).

All pairwise $\Phi_{\mathrm{ST}}$ values showed significant genetic differences among the Iberian groups visualized in the network of haplotypes and phylogenetic tree (Table 4): the smallest pairwise $\Phi_{\mathrm{ST}}$ was found between south central and south west $\left(\Phi_{\mathrm{ST}}\right.$ $0.70297, P<0.01$; Table 4) and the highest $\Phi_{\mathrm{ST}}$ was found between the north west and the Ebro ( $\Phi_{\mathrm{ST}} 0.93775, P<0.01$; Table 4$)$. Moreover, the pairwise $\Phi_{\mathrm{ST}}$ values assessed for individual Iberian populations showed significant genetic differences among them, with only three pairs showing no significant genetic differences (Table 5).

\section{DISCUSSION}

This study represents the first attempt to uncover the genetic diversity of $A$. anatina across its
European distribution range, based on $\mathrm{CO} 1$ sequences. The detailed analysis of the mtDNA genetic variation clearly revealed three major mtDNA clades, and within each one, several geographically related haplogroups with generally non-overlapping geographic distributions. These results were further supported by the hierarchical analyses of molecular variance that showed significant genetic differences among the three mtDNA clades. However, it would be desirable for future studies to supplement the number of individuals and populations used in this present one, in order to retrieve a stronger statistical hierarchical analysis of genetic variation.

The results obtained in this study strongly indicate that $A$. anatina has a complex phylogeographic history with high genetic diversity found within its range. Several mtDNA allopatric lineages were revealed, which can be explained by the occurrence of multiple refugia for this species during the last glacial periods, so that considerable genetic diversity has been conserved. In addition, the results seem to support the idea of multiple refugia within the Iberian Peninsula, with the existence of at least three (north west, south and Ebro) during Pleistocene glaciations.

Following a similar pattern to Iberia, other taxa have shown a high level of endemism in Italy, especially in the Calabria region (southern Italy) (e.g. red squirrel: Grill et al., 2009; pygmy shrews: Vega et al., 2010). Nagel et al. (1996) using allozymes, described the presence of two Italian Anodonta groups (groups I and II) which exist in sympatry with little or no gene flow. These Anodonta groups might correspond to the findings of the present study (for Lake Maggiore and Lake Castel dell'Alpi; Table 1 and Figure 1) but further sampling is needed. This will be important not only to clarify the number of possible genetically distinct groups that may exist in Italy but will also 


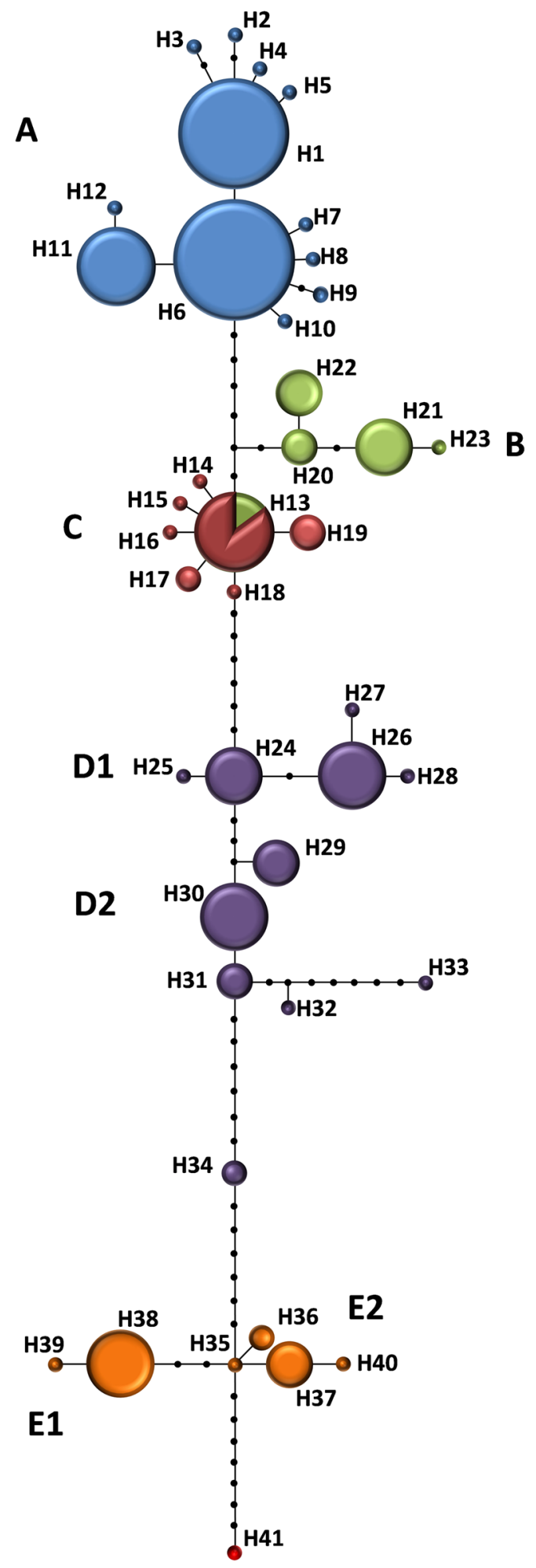

Figure 3. Haplotype (TCS) network showing the relationships of Anodonta anatina specimens, inferred from the same individuals sequenced. Circle size is proportional to the observed haplotype frequencies and black points represent unobserved haplotypes and potential intermediates. Colours correspond to the major mtDNA groups found in the phylogeny (Figure 2).
Table 3. Analysis of molecular variance (AMOVA) measured among populations of Anodonta anatina for its entire range and for Iberia (see text for details)

\begin{tabular}{llccc}
\hline $\begin{array}{l}\text { Structure } \\
\text { tested }\end{array}$ & Source of variation & $\begin{array}{c}\% \\
\text { Variance }\end{array}$ & $\begin{array}{c}\text { Fixation } \\
\text { indices }\end{array}$ & $P$ \\
\hline $\begin{array}{l}\text { Entire } \\
\text { range }\end{array}$ & $\begin{array}{l}\text { Among regions } \\
\text { Among populations } / \\
\text { within regions } \\
\end{array}$ & 54.25 & 0.54248 & $<0.01$ \\
& Within populations & 9.93 & 0.78300 & $<0.01$ \\
\hline Iberia & Among regions & 71.92 & 0.90072 & $<0.01$ \\
& $\begin{array}{c}\text { Among populations / } \\
\text { within regions }\end{array}$ & 6.71 & 0.23897 & $<0.01$ \\
& Within populations & 21.37 & 0.78628 & $<0.01$ \\
\hline
\end{tabular}

Table 4. Genetic differentiation of Anodonta anatina $\left(\Phi_{\mathrm{ST}}\right)$ among the Iberian population groups. Associated p-values were all highly significant $(P<0.01$; probability that a random value obtained from 10000 permutations is greater than the observed value)

\begin{tabular}{lccc}
\hline & North-West & South-Central & South-West \\
\hline North-West & & & \\
South-Central & 0.81575 & & \\
South-West & 0.84095 & 0.70297 & \\
Ebro & 0.93775 & 0.88215 & 0.91813 \\
\hline
\end{tabular}

be fundamental in understanding the genetic closeness of the Italian and Ebro (Iberia) populations. Although never observed in native European freshwater mussels, the close affinity between Italian and Ebro haplotypes (0.6\% uncorrected distances for this study) has been described for other freshwater taxa (e.g. freshwater fish and amphibians: Vargas et al., 1998; and aquatic snails: Bunje, 2005), where it is postulated to have been maintained through the lower extremes of the Pyrenees (Vargas et al., 1998). Only by thorough analyses of the French Mediterranean populations (not included in this study) can this be clarified.

Regarding the rest of the species distribution, Nagel et al. (1996) using allozymes described two closely related groups within A. anatina from the central and western European populations. One included all the populations from the drainage basins of the rivers Seine, Rhine, and from rivers that drain to the North Sea, and this was closely related to a second group that encompassed the populations of the rivers Loire, Rhône, Danube and their respective tributaries. In addition to this finding, Anodonta group I (from Italy; see above) 
Table 5. Genetic differentiation of Anodonta anatina $\left(\Phi_{\mathrm{ST}}\right)$ among the Iberian populations. Associated $P$-values were all highly significant $(P<0.01$; probability that a random value obtained from 10000 permutations is greater than observed value) except for bold values with *

\begin{tabular}{|c|c|c|c|c|c|c|c|c|c|}
\hline & Minho & Douro & Vouga & Mondego & Tejo & Guadiana & Sado & Guadalquivir & Barbate \\
\hline Douro & 0.42129 & & & & & & & & \\
\hline Mondego & 0.63492 & 0.38434 & 0.64405 & & & & & & \\
\hline Tejo & 0.44797 & 0.31148 & 0.48135 & $0.01260 *$ & & & & & \\
\hline Guadiana & 0.83794 & 0.85389 & 0.85771 & 0.89014 & 0.83719 & & & & \\
\hline Sado & 0.90950 & 0.89514 & 0.91863 & 0.94819 & 0.89822 & $0.13742 *$ & & & \\
\hline Ebro & 0.54280 & 0.67524 & 0.60090 & 0.62978 & 0.58689 & 0.45740 & 0.51711 & $0.25032 *$ & 0.37189 \\
\hline
\end{tabular}

was more related to the central and western European groups than to Anodonta group II (also from Italy). The new mtDNA results presented here are somewhat concordant with those obtained by Nagel et al. (1996) and provide additional details on the structure of the species: not only do the southern European peninsulas, Iberia and Italy, seem to have acted as important glacial refugia for $A$. anatina (isolation within refugia during Pleistocene glaciations), but at least another glacial refugium, somewhere in central-east Europe, seems to have also existed. The haplotype distinctiveness and position in the network, especially of both the Polish and Ukrainian samples, point out the necessity for further sampling in these regions. As an example, in the aquatic snail Theodoxus fluviatilis (Linnaeus, 1789) several independent mtDNA lineages were found in different drainages of the Black Sea, Ukraine (Bunje, 2005), which indicates that further sampling for A. anatina may also provide evidence for refugia within the refugium in this region. A number of missing haplotypes were detected for the European group (clade 2). This situation may result from incomplete geographical sampling or alternatively by missing haplotypes that may now be extinct. Either way, the mtDNA genetic variation reveals a complex phylogeographic history of $A$. anatina in Europe, especially in central regions.

In North America, the Pleistocene glaciations also had major impacts on the genetic structure of many species (Hewitt, 1996). Several studies on freshwater mussels describe populations in unglaciated regions that show greater genetic diversity than more northerly regions (King et al., 1999; Serb et al., 2003; Zanatta and Murphy,
2008; Zanatta and Harris, 2013; Inoue et al., 2014). Moreover, studies using co-occurring mussel species indicate that they may have a very different genetic structure in the same habitats (Elderkin et al., 2008; Zanatta and Harris, 2013). The genus Anodonta also occurs in western North America where it contains three highly divergent lineages (Chong et al., 2008). In recent studies, Mock et al. (2010, 2013) described the phylogeographical subdivision in the most widespread and diverse of these lineages and concluded that the observed genetic structure corresponded to the major hydrologic basins. Unfortunately, studies on the genetic diversity of freshwater mussels in Europe are still very scarce. An exception are the studies conducted in Iberia on the genus Unio, that although reporting much smaller total sample sizes, point to the existence of endemisms (Araujo et al., 2009a, b; Reis and Araujo, 2009; Reis et al., 2013). Conversely, in populations of Margaritifera margaritifera (Linnaeus, 1758) from several drainages in Spain (Iberia) only two variable sites were found in a $657 \mathrm{bp}$ segment of the COI gene (Machordom et al., 2003). In addition, the pattern obtained in the present study for $A$. anatina is very different from the one seen for $P$. complanata within the UK, where levels of genetic differentiation are modest with surprisingly good gene flow between widely dispersed populations (Skidmore et al., 2010). Those patterns were explained by human activities such as fish stocking and the interconnectivity of the different drainages.

The phylogeography of Iberian freshwater fish species strongly reflects the geomorphological history of Iberian water drainages and formation 
of mountain ranges, with several areas being identified as harbouring distinct native fish lineages (Antunes et al., 2006; Filipe et al., 2009; Doadrio et al., 2013). Unfortunately, 52\% of Iberian fish species are now catalogued as threatened (according to IUCN criteria; Maceda-Veiga, 2013). Mussel species such as $A$. anatina, considered as host generalists, are often supposed to be safe from host limitation despite their observed population declines. However, Douda et al. (2013) found that the host fish range in A. anatina is more restrictive than first assumed. As conservation efforts must consider both the mussels and their native hosts, the confirmation of geographically distinct genotypes in $A$. anatina indicates a need for the development of management strategies directed towards the conservation of localized populations as well as their hosts. Furthermore, future host studies should include each of the major geographically distinct genotypes of $A$. anatina depicted in the present study.

Additional research efforts are needed and they must include more markers and individuals from the whole range. Even so, three major groups can be defined based on the present results, with each deserving individual attention from a conservation perspective. Although $A$. anatina is still the most common European unionoid and the one with the widest distribution range, the geographical coverage and conservation status of the three major groups depicted in this study is very different. In Iberia (clade 1) the species has decreased dramatically over the last two decades, mainly in Spain where it is becoming rare and is already protected in some regions (CMADS, 2007; Araujo et al., 2009b). The majority of the European populations fall into clade 2, which seems to be generally stable although the species is already threatened and protected in some countries within this clade (e.g. Austria, Germany, Ireland and Romania) (Sárkány-Kiss, 2003; Reischütz and Reischütz, 2007; Byrne et al., 2009; Binot-Hafke et al., 2011). Clade 3 includes only the Ebro and the Italian populations, thus covering a small distributional range in which $A$. anatina is decreasing dramatically and facing multiple threats (e.g. eutrophication, water abstraction and the introduction of invasive species; Cianfanelli et al., 2007; Cappelletti et al., 2009; Halcon, 2011).

In summary, the results of this study have several direct consequences for the conservation of $A$. anatina because several mtDNA lineages were found that represent geographically distinct genotypes. Although this preliminary study was based solely on $\mathrm{CO} 1$, the results are of great interest in conservation planning because the data suggest that $A$. anatina has at least three management units. The analysis of mitochondrial DNA was the primary tool used in this phylogeographic study, owing to the fast mutation rate of mitochondrial genes and because maternal inheritance makes it possible to determine where a species was able to establish populations (Avise, 2000). However, the lower mutation rate and slower fixation rate of nuclear genes, when compared with the mitochondrial genome, means that nuclear genealogies may be more indicative of older demographic events (Avise, 2004). Therefore, in future analyses, the distribution of ancestral nuclear alleles could be useful in identifying refugial areas for this species. In addition, using microsatellites to estimate effective population sizes and to reflect current gene flow will also be of great utility. Finally, and as noted previously (Chong et al., 2008), it seems that the phylogeny of the Anodonta genus needs further evaluation as it appears not to be monophyletic, with $A$. cygnea and $P$. complanata forming a sister clade to A. anatina.

\section{ACKNOWLEDGEMENTS}

This work was supported financially by the Portuguese Foundation for Science and Technology (FCT) project PTDC/AAC-AMB/ $117688 / 2010$, and partly by the European Regional Development Fund through COMPETE, under the project PEst-C/MAR/LA0015/2011. We would like to thank our collaborators who kindly provided us with tissue samples: Erika Bódis, Karel Douda, Oksana Stolyar, Arpad Benko-Kiss, Nicoletta Riccardi. Marianna Soroka and Larissa Yanovich gave us the exact locations of their previously sequenced animals. We thank 
José María Irurita, José Miguel Barea Azcón, Keiko Nakamura, Pablo Redin and Esther Penin for all their help during the Spanish field campaigns. Official capture and sampling licences were issued by Junta de Castilla y León (Consejería de Fomento y Medio Ambiente EP/CYL/331/ 2012, de 17 de Abril de 2012); Junta de Andalucia (Consejería de Medio Ambiente- SGYB/FOA/ AFR/SFS, de 17 de Julio de 2012); Xunta de Galicia (Consellería de Medio Ambiente- 539/2012 de 15 de Setembro de 2012); Gobierno de Aragón (Dirección General de Conservación del Medio Natural- 136.071/2012 de 12 de Julio de 2012).

\section{REFERENCES}

Aldridge DC, Fayle TM, Jackson N. 2007. Freshwater mussel abundance predicts biodiversity in UK lowland rivers. Aquatic Conservation: Marine and Freshwater Ecosystems 17: $554-564$.

Antunes A, Faria R, Johnson W, Guyomard R, Alexandrino P. 2006. Life on the edge: the long-term persistence and contrasting spatial genetic structure of distinct brown trout life histories at their ecological limits. Journal of Heredity 97: 193-205.

Araujo R, Gómez I, Machordom A. 2005. The identity and biology of Unio mancus $(=U$. elongatulus) (Bivalvia: Unionidae) in the Iberian Peninsula. Journal of Molluscan Studies 71: 25-31.

Araujo R, Toledo C, Machordom A. 2009a. Redescription of Unio gibbus Spengler, 1793, a west palaearctic freshwater mussel with hookless glochidia. Malacologia 51: 131-141.

Araujo R, Reis J, Machordom A, Toledo C, Madeira MJ, Gómez I, Velasco JC, Morales J, Barea JM, Ondina P, Ayala I. 2009b. The naiades of the Iberian Peninsula. Iberus 27: 7-72.

Avise JC. 2000. Phylogeography: the History and Formation of Species. Harvard University Press: Cambridge, MA.

Avise JC. 2004. Molecular Markers, Natural History and Evolution, 2nd edn. Sinauer Associates: Sunderland, MA.

Barnhart MC, Haag WR, Roston WN. 2008. Adaptations to host infection and larval parasitism in Unionoida. Journal of the North American Benthological Society 27: 370-394.

Bauer G. 2001. Framework and driving forces for the evolution of naiad life histories. In Ecology and Evolution of the Freshwater Mussels Unionoida, Bauer G, Wachtler K (eds). Springer-Verlag: Berlin/Heidelberg; 223-255.

Benke M, Brändle M, Albrecht C, Wilke T. 2009. Pleistocene phylogeography and phylogenetic concordance in cold-adapted spring snails (Bythinella spp.) Molecular Ecology 18: 890-903.

Bilton DT, Mirol PM, Mascheretti S, Fredga K, Zima J, Searle JB. 1998. Mediterranean Europe as an area of endemism for small mammals rather than a source for northwards postglacial colonization. Proceedings of the Royal Society B: Biological Sciences 265: 1219-1226.

Binot-Hafke M, Balzer S, Becker N, Gruttke H, Haup H, Hofbauer N, Ludwig G, Matzke-Hajek G, Strauch M.
2011. Rote Liste gefährdeter Tiere, Pflanzen und Pilze Deutschlands Band 3: Wirbellose Tiere (Teil 1). Bundesamt für Naturschutz, Bonn-Bad Godesberg, Germany.

Bunje PME. 2005. Pan-European phylogeography of the aquatic snail Theodoxus fluviatilis (Gastropoda: Neritidae). Molecular Ecology 14: 4323-4340.

Byrne A, Moorkens EA, Anderson R, Killeen IJ, Regan EC. 2009. Ireland Red List No. 2 - Non-marine molluscs. National Parks and Wildlife Service. Department of the Environment, Heritage and Local Government, Dublin, Ireland.

Callejas C, Ochando MD. 2000. Recent radiation of Iberian barbel fish (Teleostei, Cyprinidae) inferred from cytochrome b genes. Journal of Heredity 91: 283-288.

Cappelletti C, Cianfanelli S, Beltrami ME, Ciutti F. 2009. Sinanodonta woodiana (Lea, 1834) (Bivalvia: Unionidae): a new non-indigenous species in Lake Garda (Italy). Aquatic Invasions 4: 685-688.

Carmona JA, Domínguez J, Doadrio I. 2000. Congruence between allozyme and cytochrome $\mathrm{b}$ gene sequence data in assessing genetic differentiation within the Iberian endemic Chondrostoma lemmingii (Pisces: Cyprinidae). Heredity 84: 721-732.

Chong JP, Brim Box JC, Howard JK, Wolf D, Myers TL, Mock K. 2008. Three deeply divided lineages of the freshwater mussel genus Anodonta in western North America. Conservation Genetics 9: 1303-1309.

Cianfanelli S, Lori E, Bodon M. 2007. Non-indigenous freshwater molluses and their distribution in Italy. In Biological Invaders in Inland Waters: Profiles, Distribution, and Threats, Gherardi F (ed.). Springer: Dordrecht, The Netherlands; 103-121.

Clement M, Posada D, Crandall KA. 2000. TCS: a computer program to estimate gene genealogies. Molecular Ecology 9: $1657-1659$.

CMADS. 2007. Decreto 88/2007, de 19 de abril, por el que se regula el Catálogo gallego de especies amenazadas (Galician Threatened Species Catalogue). Diario Oficial de Galicia. Consellería de Medio Ambiente y Desarrollo Sostenible. Spain.

Coelho MM, Mesquita N, Collares-Pereira MJ. 2005. Chondrostoma almacai, a new cyprinid species from the southwest of Portugal, Iberian Peninsula. Folia Zoologica 54: 201-212.

Doadrio I, Carmona JA, Machordom A. 2013. Haplotype diversity and phylogenetic relationships among the Iberian barbels (Barbus, Cyprinidae) reveal two evolutionary lineages. The American Genetic Association. Journal of Heredity 93: 140-147.

Douda K, Lopes-Lima M, Hinzmann M, Machado J, Varandas S, Teixeira A, Sousa R, 2013. Biotic homogenization as a threat to native affiliate species: fish introductions dilute freshwater mussel's resources. Diversity and Distributions 19: 933-942.

Elderkin CL, Christian AD, Metcalfe-Smith JL, Berg DJ. 2008. Population genetics and phylogeography of freshwater mussels in North America, Elliptio dilatata and Actinonaias ligamentina (Bivalvia: Unionidae). Molecular Ecology 17: 2149-2163.

Excoffier L, Lischer HEL. 2010. Arlequin suite ver 3.5: a new series of programs to perform population genetics analyses under Linux and Windows. Molecular Ecology Resources 10: $564-567$. 
Filipe A, Araujo BM, Doadrio I, Angermeier PL, Collares-Pereira MJ. 2009. Biogeography of Iberian freshwater fishes revisited: the roles of historical versus contemporary constraints. Journal of Biogeography 36: 2096-2110.

Folmer O, Black M, Hoeh W, Lutz R, Vrijenhoek R. 1994. DNA primers for amplification of mitochondrial cytochrome $c$ oxidase subunit I from diverse metazoan invertebrates. Molecular Marine Biology and Biotechnology 3: 294-299.

Geist J, Söderberg H, Karlberg A, Kuehn R. 2010. Drainage-independent genetic structure and high genetic diversity of endangered freshwater pearl mussels (Margaritifera margaritifera) in northern Europe. Conservation Genetics 11: $1339-1350$.

Gómez A, Lunt DH. 2007. Refugia within refugia: patterns of phylogeographic concordance in the Iberian Peninsula. In Phylogeography in Southern European Refugia: Evolutionary Perspectives on the Origin and Conservation of European Biodiversity, Weiss S, Ferrand N (eds). Springer: Dordrecht, The Netherlands; 155-188.

Graf DL. 2007. Palearctic freshwater mussel (Mollusca: Bivalvia: Unionoida) diversity and the Comparatory Method as a species concept. Proceedings of the Academy of Natural Sciences of Philadelphia 156: 71-88.

Graf DL, Cummings KS. 2007. Review of the systematics and global diversity of freshwater mussel species (Bivalvia: Unionoida). Journal of Molluscan Studies 73: 291-314.

Grill A, Amori G, Aloise G, Lisi I, Tosi G, Wauters LA, Randi E. 2009. Molecular phylogeography of European Sciurus vulgaris: refuge within refugia? Molecular Ecology 18: 2687-2699.

Guindon S, Gascuel O. 2003. A simple, fast, and accurate algorithm to estimate large phylogenies by maximum likelihood. Systematic Biology 52: 696-704.

Halcon RMA. 2011. Bivalvos de agua dulce en la Delimitación Comarcal de Zaragoza. In Delimitación Comarcal de Zaragoza, Aragón IA, González, JLO (eds). Gobierno de Aragón: Zaragoza, Spain; 67-69.

Hall TA. 1999. BioEdit: a user-friendly biological sequence alignment editor and analysis program for Windows 95/98/ NT. Nucleic Acids Symposium Series 41: 95-98. North Carolina State University: Raleigh, NC.

Hewitt GM. 1996. Some genetic consequences of ice ages, and their role in divergence and speciation. Biological Journal of the Linnean Society 58: 247-276.

Hewitt GM. 1999. Postglacial recolonization of European biota. Biological Journal of the Linnean Society 68: 87-112.

Hewitt GM. 2000. The genetic legacy of the Quaternary ice ages. Nature 405: 907-913.

Hinzmann M, Lopes-Lima M, Teixeira A, Varandas S, Sousa R, Lopes A, Froufe E, Machado J. 2013. Sexual strategy and reproductive cycle of Anodonta anatina (L., 1758): notes on hermaphroditism. Journal of Experimental Zoology Part A 309: 378-390.

Huff SW, Campbell D, Gustafson DL, Lydeard C, Altaba CR, Giribet G. 2004. Investigations into the phylogenetic relationships of freshwater pearl mussels (Bivalvia: Margaritiferidae) based on molecular data: implications for their taxonomy and biogeography. Journal of Molluscan Studies 70: 379-388.

Inoue K, Monroe EM, Elderkin CL, Berg DJ. 2014. Phylogeographic and population genetic analyses reveal
Pleistocene isolation followed by high gene flow in a wide ranging, but endangered, freshwater mussel. Heredity 112: $282-290$.

Källersjö M, von Proschwitz T, Lundberg S, Eldanäs P, Erséus C. 2005. Evaluation of ITS rDNA as a complement to mitochondrial gene sequences for phylogenetic studies in freshwater mussels: an example using Unionidae from north-western Europe. Zoologica Scripta 34: 415-424.

King TL, Eackles MS, Gjetvaj B, Hoeh WR. 1999. Intraspecific phylogeography of Lasmigona subviridis (Bivalvia: Unionidae): conservation implications of range discontinuity. Molecular Ecology 8: S65-S78.

Maceda-Veiga A. 2013. Towards the conservation of freshwater fish: Iberian rivers as an example of threats and management practices. Reviews in Fish Biology and Fisheries 23: 1-22.

Machordom A, Araujo R, Erpenbeck D, Ramos MA. 2003. Phylogeography and conservation genetics of endangered European Margaritiferidae (Bivalvia: Unionoidea). Biological Journal of the Linnean Society 78: 235-252.

Mock KE, Box JC, Chong JP, Howard JK, Nez DA, Wolf D, Gardner RS. 2010. Genetic structuring in the freshwater mussel Anodonta corresponds with major hydrologic basins in the western United States. Molecular Ecology 19: $569-591$.

Mock KE, Box JC, Chong JP, Furnish J, Howard JK. 2013. Comparison of population genetic patterns in two widespread freshwater mussels with contrasting life histories in western North America. Molecular Ecology 22: 6060-6073.

Nagel KO, Badino G, Alessandria B. 1996. Population genetics of European Anodontinae (Bivalvia: Unionidae). Journal of Molluscan Studies 62: 343-357.

Pauls SU, Lumbsch HT, Haase P. 2006. Phylogeography of the montane caddisfly Drusus discolor: evidence for multiple refugia and periglacial survival. Molecular Ecology 15: 2153-2169.

Plazzi F, Ceregato A, Taviani M, Passamonti M. 2011. A molecular phylogeny of bivalve mollusks: ancient radiations and divergences as revealed by mitochondrial genes. PLoS ONE 6: e27147.

Posada D. 2008. jModelTest: phylogenetic model averaging. Molecular Biology and Evolution 25: 1253-1256.

Posada D, Crandall K. 2001. Evaluation of methods for detecting recombination from DNA sequences: computer simulations. Proceedings of the National Academic of Sciences of the United States of America 98: 13757-13762.

Rambaut A, Drummond AJ. 2007. Tracer v1.4. Available at http://beast.bio.ed.ac.uk/Tracer.

Reis J, Araujo R. 2009. Redescription of Unio tumidiformis Castro, 1885 (Bivalvia, Unionidae), an endemism from the south-western Iberian Peninsula. Journal of Natural History 43: 1929-1945.

Reis J, Machordom A, Araujo R. 2013. Morphological and molecular diversity of unionidae (Mollusca, Bivalvia) from Portugal. Graellsia 69: 17-36.

Reischütz A, Reischütz PL. 2007. Rote Liste der Weichtiere (Mollusca) Österreichs. In Rote Listen gefährdeter Tiere Österreichs. Checklisten, Gefährdungsanalysen, Handlungsbedarf. Teil 2. Grüne Reihe des BLFUW, Zulka P (ed). Böhlauverlag: Wien; 363-433.

Ronquist F, Huelsenbeck JP. 2003. MrBayes 3: Bayesian phylogenetic inference under mixed models. Bioinformatics 19: 1572-1574. 
Sambrook J, Fritsch EF, Maniatis T. 1989. Molecular Cloning: a Laboratory Manual. Cold Spring Harbour Press: New York.

Sárkány-Kiss, A. 2003. Az erdélyi folyók vízi puhatestű faunájának egykori és jelenlegi helyzete. A minőségi és mennyiségi dinamikák ökológiai értelmezése, javaslatok. In: Ujvárosi, L. (szerk.): Erdély folyóinak természeti állapota. Sapientia Könyvek, Természettudomány, Kolozsvár, Románia; 107-150.

Serb JM, Buhay JE, Lydeard C. 2003. Molecular systematics of the North American freshwater bivalve genus Quadrula (Unionidae: Ambleminae) based on mitochondrial ND1 sequences. Molecular Phylogenetics and Evolution 28: 1-11.

Skidmore R, Leach C, Hoffman J, Amos W, Aldridge DC. 2010. Conservation genetics of the endangered depressed river mussel, Pseudanodonta complanata, using amplified fragment length polymorphism (AFLP) markers. Aquatic Conservation: Marine and Freshwater Ecosystems 20: 560-567.

Soroka M. 2008. Identification of gender-associated mitochondrial haplotypes in Anodonta anatina (Bivalvia: Unionidae). Folia Malacologica 16: 21-26.

Soroka M. 2010. Characteristics of mitochondrial DNA of unionid bivalves (Mollusca: Bivalvia: Unionidae). I. Detection and characteristic of double uniparental inheritance (DUI) of unionid mitochondrial. Folia Malacologica 18: 147-188.

Sousa R, Freire R, Rufino M, Méndez J, Gaspar M, Antunes C, Guilhermino L. 2007. Genetic and shell morphological variability of the invasive bivalve Corbicula fluminea (Müller, 1774) in two Portuguese estuaries. Estuarine, Coastal and Shelf Science 74: 166-174.

Sousa R, Ilarri M, Souza AT, Antunes C, Guilhermino L. 2011. Rapid declining trend of the greater European peaclam at the periphery of its distribution. Annales de Limnologie - International Journal of Limnology 47: 211-219.

Sousa R, Varandas S, Cortes R, Teixeira A, Lopes-Lima M, Machado J, Guilhermino L. 2012. Massive die-offs of freshwater bivalves as resource pulses. Annales de Limnologie - International Journal of Limnology 48: 105-112.

Strayer DL. 2008. Freshwater Mussel Ecology: A Multifactor Approach to Distribution and Abundance. University of California Press: Berkeley, CA.

Tamura K, Nei M. 1993. Estimation of the number of nucleotide substitutions in the control region of mitochondrial DNA in humans and chimpanzees. Molecular Biologyand Evolution 10: $512-526$.

Tamura K, Peterson D, Peterson N, Stecher G, Nei M, Kumar S. 2011. MEGA5: Molecular evolutionary genetics analysis using maximum likelihood, evolutionary distance, and maximum parsimony methods. Molecular Biology and Evolution 28: 2731-2739.

Vargas JM, Real R, Guerrero JC. 1998. Biogeographical regions of the Iberian Peninsula based on freshwater fish and amphibian distributions. Ecography 21: 371-382.

Vaughn C. 2010. Biodiversity losses and ecosystem function in freshwaters: emerging conclusions and research directions. Bioscience 60: 25-35.

Vega R, Amori G, Aloise G, Cellini S, Loy A, Searle JB. 2010. Genetic and morphological variation in a Mediterranean glacial refugium: evidence from Italian pygmy shrews, Sorex minutus (Mammalia: Soricomorpha). Biological Journal of the Linnean Society 100: 774-787.

Walker JM, Curole JP, Wade DE, Chapman EG, Bogan AE, Watters GT, Hoeh WR. 2006. Taxonomic distribution and phylogenetic utility of gender-associated mitochondrial genomes in the Unionoida (Bivalvia). Malacologia 48: 265-282.

Walker JM, Bogan AE, Bonfiglio EA, Campbell DC, Christian AD, Curole JP, Harris JL, Wojtecki RJ, Hoeh WR. 2007. Primers for amplifying the hypervariable, male-transmitted COII-COI junction region in amblemine freshwater mussels (Bivalvia: Unionoidea: Ambleminae). Molecular Ecology Notes 7: 489-491.

Weiss S, Ferrand N. 2007. Phylogeography of Southern European Refugia. Springer: Dordrecht.

Williams JD, Melvin J, Warren L, Cummings KS, Harris JL, Neves RJ. 1993. Conservation status of freshwater mussels of the United States and Canada. Fisheries 18: 6-22.

Zanatta DT, Harris AT. 2013. Phylogeography and genetic variability of the freshwater mussels (Bivalvia: Unionidae) ellipse, Venustaconcha ellipsiformis (Conrad 1836), and bleeding tooth, $V$. pleasii (Marsh 1891). American Malacological Bulletin 31: 267-279.

Zanatta DT, Murphy RW. 2008. The phylogeographical and management implications of genetic population structure in the imperiled snuffbox mussel, Epioblasma triquetra (Bivalvia: Unionidae). Biological Journal of the Linnean Society 94: 371-384.

Zieritz A, Aldridge DC. 2009. Identification of ecophenotypic trends within three European freshwater mussel species (Bivalvia: Unionoida) using traditional and modern morphometric techniques. Biological Journal of the Linnean Society 98: 814-825.

Zieritz A, Hoffman JI, Amos W, Aldridge DC. 2010. Phenotypic plasticity and genetic isolation-by-distance in the freshwater mussel Unio pictorum (Mollusca: Unionidae). Evolutionary Ecology 24: 923-938. 